\title{
Comparative Performance of Different Methods of Harvesting of Wheat Crop in Western Madhya Pradesh, India
}

\author{
G. S. Rajesh Gupta $^{1}$, Chundawat $^{1}$ and A. L. Basediya ${ }^{2}$ \\ ${ }^{1}$ RVSKVV, Krishi Vigyan Kendra, Mandsaur, M.P. \\ ${ }^{2}$ RVSKVV, Krishi Vigyan Kendra, Shivpuri, M.P., India \\ *Corresponding author
}

\begin{abstract}
A B S T R A C T
The field experiments were conducted at farmer fields in Mandsaur district of Madhya Pradesh to study the comparative performance of different harvesting methods for wheat crop consisting of three treatments viz., self-propelled reaper binder with crop bundle collection in the field manually (T1), self-propelled vertical conveyer reaper with crop bundles making and their collection in the field manually (T2), and manual harvesting using sickle with crop bundle making and collection in the field (T3). The self propelled reaper binder shows significant effect on field efficiency with 88.43 percent saving of labour in comparison to manual harvesting of wheat. The harvesting losses were found minimum in treatment T3 $(21.3 \mathrm{~kg} / \mathrm{ha}, 1.52 \%)$ whereas maximum in treatment T1 (28.8 $\mathrm{kg} / \mathrm{ha}, 2.06 \%)$ followed by treatment $\mathrm{T} 2(24.5 \mathrm{~kg} / \mathrm{ha}, 1.75 \%)$. Also, the lowest cost of harvesting was found in treatment T3 (2875 Rs/ha) with a payback period of $535 \mathrm{hr}$. Hence, the harvesting of wheat by self-propelled reaper binder with crop bundle collection in the field manually should be advocated over manually harvesting and self-propelled vertical conveyer reaper in western Madhya Pradesh.
\end{abstract}

\section{Keywords}

Wheat, Selfpropelled, Reaper binder, Field efficiency, Harvesting losses

Article Info

Accepted:

18 April 2020

Available Online:

10 May 2020

\section{Introduction}

Harvesting is an operation carried out after the maturity of crop. It includes the cutting of crops and binding the straws. Harvesting of crops is one of the important agricultural operations which demands considerable amount of labour. Harvesting of wheat crop in western Madhya Pradesh is mainly done manually by hand using sickle which is labour intensive and delayed due to labour shortage to overcome. The availability and cost of labour during harvesting season are the serious problems. It is estimated that harvesting and threshing of crops consume about the 25-30 per cent of the total requirement of the production system (Ashoka et al., 2012). Timely harvest of the crop is vital to achieve better quality and higher yield of the crop. The losses are 
minimum at optimum harvesting time, also late harvesting causes 3 percent loss in the first week to about 7 percent loss of grain in the third week after optimum time of harvesting (Saxena and Ojha, 1985).

The shortage of labour during harvesting season and vagaries of the weather cause greater loss to the farmers. Rapid urbanization and migration of agricultural labour resulted in late harvesting, causing heavy grain losses (Iqbal, 1985). It is therefore, essential to adopt the mechanical methods so that the timeliness in harvesting operation could be ensured and field losses are minimized to increase the productivity and production on the farm. There are four types of technologies available for cereal crops in India namely, traditional hand tools like sickle, manual reaper, selfpropelled reaper binder and modern combine harvester.

Tractor operated machines are being used by the farmers, but a high cost power source is involved with the machine. Power tillers are popular in selected regions, particularly in some of the paddy growing areas and hilly regions and hence the use of power tiller operated machine is limited. Self-propelled walk behind type reapers are also available. The locally manufactured and commercially available tractor front mounted reapers can harvest $0.284 \mathrm{ha} / \mathrm{h}$ and saves $129 \mathrm{man}-\mathrm{h} / \mathrm{ha}$ compared to traditional manual harvesting with sickle for wheat crop (Gajendra Singh et al., 1988).

A riding type self-propelled reaper binder powered by 4.5 horse power diesel engine, has been found to increase the working efficiency and eliminate human drudgery involved in walking behind the machine. The self-propelled unit provided much better maneuverability and other better visibility and control by the operator in comparison to trailed machine (Mishra, 1983). Therefore, the field study was conducted at farmer's fields to evaluate the performance of self propelled reaper binder for harvesting of wheat crop in Mandsaur district of Madhya Pradesh.

\section{Materials and Methods}

The field study was conducted during harvesting period of rabi season 2019 at farmer's field in Mandsaur district of Madhya Pradesh. The area is situated in western part of Madhya Pradesh which falls under agroclimatic zone of Malwa plateau. Mandsaur belongs to sub-tropical climate having a mean temperature range of minimum $5^{\circ} \mathrm{C}$ and maximum $44^{\circ} \mathrm{C}$ in winter and summer, respectively. The average annual rainfall in the district is $786.6 \mathrm{~mm}$. The topography of the experimental sites was uniform and levelled and the soil is clayey in texture with $45 \mathrm{~cm}$ depth. The field experiments were conducted at farmer fields to study the comparative performance of different harvesting methods for wheat crop consisting of three treatments. The treatments with ten replications that were undertaken during the study test are as follows.

Treatment (T1): Manual harvesting using sickle, crop bundle making and collection in the field

Treatment (T2): Self-propelled vertical conveyer reaper + crop bundles making and their collection in the field manually

Treatment (T3): Self-propelled reaper binder + crop bundle collection in the field manually

The reaper binder machine has different structure and working rows to meet different requirements of customers. The technical specifications of reaper binder which was used in the present study are given in Table 1 . The physical construction is divided into three 
parts: steering mechanism, engine mounting, and cutting and binder mechanism.

(a) Steering mechanism: Steering or direction controlling of machine is done by foot, paddle is provided to control direction.

(b) Engine mounting: Chassis is provided to mount the $10 \mathrm{HP}$ engine of machine.

(c) Header: Blades are mounted on the base and binder mechanism is provided to bind the cut straws by means of sting. After cutting, the crop is conveyed vertically to the binding mechanism and released to the ground in the form of bundles.

\section{Machine working hours}

The actual working time of machine was measured in the field using a stop watch. The time losses due to turnings were not taken into account. Time lost in breakdowns were recorded and deducted from the total time.

\section{Speed of operation}

The speed of operation was varied from 1.9 to $2.6 \mathrm{~km} / \mathrm{h}$. The speed of operation was calculated by using equation as given below:

$\mathrm{S}=72 / \mathrm{T}$

Where, $\mathrm{S}=$ Speed of operation $(\mathrm{km} / \mathrm{h})$

$\mathrm{T}=$ Time needed to cover $20 \mathrm{~m}$ distance $(\mathrm{sec})$

\section{Theoretical field capacity (TFC)}

The Theoretical field capacity was determined by the following relationship:

Theoretical field capacity $(\mathrm{ha} / \mathrm{h})=\mathrm{S} \times \mathrm{W} / 10$

Where,

$\mathrm{S}=$ Speed of travel $(\mathrm{km} / \mathrm{h})$

$\mathrm{W}=$ Actual width of cut $(\mathrm{m})$

\section{Effective field capacity (EFC)}

The effective field capacity was determined by the following relationship:

Effective field capacity $(\mathrm{ha} / \mathrm{h})=$ Area covered (ha) / time taken (h)

\section{Field efficiency}

The field efficiency was calculated on the basis of field data as follows:

Field efficiency $(\%)=$ EFC $($ ha/h $) /$ TFC (ha/h)

\section{Harvesting Losses (Shattering)}

It is the amount of the grains and ear heads fallen on the ground due to the shattering action of the reaper binder cutter bar and conveying.

\section{Economic analysis}

Cost analysis was carried out to compare the economics of the vertical conveyer reaper and reaper binder over manual harvesting as suggested by Kepner (1952).

\section{Results and Discussion}

The performance of self-propelled vertical conveyer reaper (treatment T2) and reaper binder (treatment T3) with respect to fuel consumption, field capacity, field efficiency, harvesting losses and labour requirement were studied and compared to manual harvesting method (Table 2 and 3).

It is evident from Table 2 that the fuel consumption $(1 / \mathrm{h})$ is non-significant between both the mechanical methods i.e., harvesting by reaper and obviously there was no fuel consumption in manual harvesting method of wheat. The theoretical field capacity of 
treatment $\mathrm{T} 1, \mathrm{~T} 2$ and $\mathrm{T} 3$ was found 0.014 ha/hr, $0.25 \mathrm{ha} / \mathrm{hr}$ and $0.30 \mathrm{ha} / \mathrm{hr}$ respectively whereas effective field capacity of treatment $\mathrm{T} 1, \mathrm{~T} 2$ and T3 was found $0.008 \mathrm{ha} / \mathrm{hr}, 0.18$ $\mathrm{ha} / \mathrm{hr}$ and $0.26 \mathrm{ha} / \mathrm{hr}$ respectively. On the basis of theoretical and effective field capacity the field efficiency of treatment T3 $(86.67 \%)$ was found higher as compared to treatment $\mathrm{T} 2$ (72.00\%) followed by treatment T1 $(57.14 \%)$.

Table.1 Technical specifications of reaper binder

\begin{tabular}{|l|l|}
\hline Component Name & Description \\
\hline Engine & 4 stroke air cooled 10 HP \\
\hline Type of fuel & Diesel \\
\hline Width of cutter & 4 feet \\
\hline Gear & 4 forward speeds and 1 reverse speed \\
\hline Weight of machine & $400 \mathrm{~kg}$ \\
\hline Dimensions & $3550 \times 1950 \times 1330 \mathrm{~mm}$ \\
\hline Rotor Speed & $1500-2000 \mathrm{rpm}$ \\
\hline Type of clutch & $\mathrm{Pad}$ \\
\hline
\end{tabular}

Table.2 Field efficiency and harvesting losses of different treatments of harvesting

\begin{tabular}{|c|l|c|c|c|}
\hline S. No. & Particulars & \multicolumn{3}{|c|}{ Treatments } \\
\hline $\mathbf{1}$ & & T1 & T2 & T3 \\
\hline $\mathbf{2}$ & Theoretical field capacity (ha/hr) & - & 1.0 & 1.2 \\
\hline $\mathbf{3}$ & Effective field capacity (ha/hr) & 0.014 & 0.25 & 0.30 \\
\hline $\mathbf{4}$ & Field efficiency (\%) & 57.14 & 0.18 & 0.26 \\
\hline $\mathbf{5}$ & Harvesting losses (kg/ha) & 28.8 & 24.5 & 86.67 \\
\hline $\mathbf{6}$ & Harvesting losses (\%) & 2.06 & 1.75 & 21.3 \\
\hline
\end{tabular}

Table.3 Economic analysis of different treatments of harvesting

\begin{tabular}{|c|l|c|c|c|}
\hline S. No. & Particulars & \multicolumn{3}{|c|}{ Treatments } \\
\cline { 3 - 4 } & & T1 & T2 & T3 \\
\hline $\mathbf{1}$ & Total labour requirement (man-h/ha) & 216 & 84.2 & 25 \\
\hline $\mathbf{2}$ & Saving in labour in comparison to T1 (\%) & - & 61.02 & 88.43 \\
\hline $\mathbf{3}$ & Cost of harvesting (Rs/ha) & 3675 & 2000 & 2500 \\
\hline $\mathbf{4}$ & Cost of bundle making (Rs/ha) & & 1110 & \\
\hline $\mathbf{5}$ & Cost of bundle collection (Rs/ha) & 375 & 375 & 375 \\
\hline $\mathbf{6}$ & Total cost of harvesting (Rs/ha) & 4050 & 3485 & 2875 \\
\hline $\mathbf{7}$ & Saving in cost in comparison to T1 (\%) & - & 13.95 & 29.01 \\
\hline $\mathbf{8}$ & Pay back period (hrs) & - & 550 & 535 \\
\hline
\end{tabular}


The harvesting losses were found minimum in treatment $\mathrm{T} 3(21.3 \mathrm{~kg} / \mathrm{ha}, 1.52 \%)$ whereas maximum in treatment $\mathrm{T} 1 \quad(28.8 \mathrm{~kg} / \mathrm{ha}$, $2.06 \%)$ followed by treatment T2 $(24.5 \mathrm{~kg} / \mathrm{ha}$, $1.75 \%)$. The present findings are in close vicinity of Gore et al., 2018.

The economic analysis of the performance all three treatments are presented in Table 3. It reveals that the labour requirement with treatment T3 (25 man-h/ha) was quit low where as in treatment T1 (216 man-h/ha) it was found very high followed by treatment T2 (84.2 man-h/ha).

The total cost of harvesting was found minimum in treatment T3 (2875 Rs/ha) whereas maximum in treatment $\mathrm{T} 1$ (4050 Rs/ha) followed by treatment T2 (3485 $\mathrm{Rs} / \mathrm{ha})$. The overall saving in cost of harvesting was observed maximum in treatment $\mathrm{T} 3(29.01 \%)$ as compared to treatment $\mathrm{T} 1$. The similar results were reported by Kumar et al., 2018. The pay back period was also worked out for the treatment $\mathrm{T} 2$ and $\mathrm{T} 3$ and it was found as $550 \mathrm{hr}$ and 535 $\mathrm{hr}$ respectively.

On the basis of the field evaluation, it can be concluded that the harvesting of wheat by self-propelled reaper binder with crop bundle collection in the field manually was found superior in comparison with self-propelled vertical conveyer reaper with crop bundles making and their collection in the field manually, and manual harvesting using sickle with crop bundle making and collection in the field. The self propelled reaper binder shows significant effect on field efficiency with 88.43 percent saving of labour in comparison to manual harvesting of wheat. It can also be concluded that the lowest cost of harvesting was found in case of self propelled reaper binder (2875 Rs/ha) with a payback period of $535 \mathrm{hr}$. Hence, the harvesting of wheat by self-propelled reaper binder with crop bundle collection in the field manually should be advocated over manually harvesting and selfpropelled vertical conveyer reaper in western Madhya Pradesh.

\section{Acknowledgment}

With sincere respect and gratitude, we would like to thank Director, ATARI, (ICAR) Zone IX, Jabalpur and Director Extension Services, RVS Agriculture University, Gwalior for providing facilities, financial support and valuable guidance for the research work.

\section{References}

Ashoka, H.G. and Prashantha, G.M. (2012). Mechanized harvesting of cereal crops An overview of the problems and factors affecting. Trends in Biosciences, Vol. 5(3): 163-165.

Gajendra Singh, Amjad., P. Chaudhary and David, Gee-Clough. (1988). Performance Evaluation of mechanical reaper in Pakistan, Agril. Mechanization in Asia, Africa \& Latin America, Vol. 19(3): 4752.

Gore, Amol., Kasal, Yuvraj G. and Shinde, Sachin. (2018). Field evaluation of self propelled reaper binder in wheat crop. Plant Archives Vol. 18(1): 551-554.

Iqbal, S., Premalatha. S., Asfa, Zahra. (1985). International journal of Dermatology, Wiley Online Library.

Kepner, R.A. (1952). Analysis of cutting section of mower, Agril. Engg. 7(1): 10-18.

Kumar, Rakesh., Paradkar, Vikas and Singh, Shashank. (2018). Economic analysis for self-propelled reaper binder over manual harvesting. Int ernational Journal of Chemical Studies, Vol. 6(6): 1219-1222.

Mishra, R.S. (1983). Field trail on reaper binder, Journal of Agril. Engg. Vol. 17 (2).

Saxena, B.B. and T.P. Ojha. (1985). Determining the effect of harvesting date on yield potential of soybean. Proceedings of silver jubilee convention, ISAE. 83. 
How to cite this article:

Rajesh Gupta, G. S., Chundawat and Basediya, A. L. 2020. Comparative Performance of Different Methods of Harvesting of Wheat Crop in Western Madhya Pradesh, India. Int.J.Curr.Microbiol.App.Sci. 9(05): 2223-2228. doi: https://doi.org/10.20546/ijcmas.2020.905.253 